\title{
Physicochemical Properties of Starch in Water Chestnut (Eleocharis kuroguwai Ohwi)
}

\author{
Sang-Kuk Kim ${ }^{1}$, Jong-Hee Shin ${ }^{1}$, Su-Yong Kim ${ }^{1}$, Hak-Yoon Kim ${ }^{2}$ and Shin-Young Park ${ }^{3 *}$ \\ 올방개 괴경 전분의 이화학적 특성
}

김상국 ${ }^{1}$, 신종희 ${ }^{1}$, 김수용 ${ }^{1}$, 김학윤 ${ }^{2}$, 박신영 $^{3 *}$

ABSTRACT The physicochemical properties of tuber starch in water chestnut have been studied. Peak viscosity, hot paste viscosity and cooling peak viscosity were 5679, 3146 and 4262 RVU, respectively. In three transition parameters, onset temperature $\left(\mathrm{T}_{o}\right)$, peak temperature $\left(\mathrm{T}_{p}\right)$, and conclusion temperature $\left(\mathrm{T}_{c}\right)$ were $64.1,68.5$ and $72.3^{\circ} \mathrm{C}$, respectively. Gelatinization enthalpy $(\Delta H$ gel) was $4.48 \mathrm{~J} / \mathrm{g}$. A-type starch has a smaller proportion $(11.4 \%)$ of short chains $(\mathrm{DP} \geq 12)$ and a larger proportion $(57.2 \%)$ of short chains $(13 \leq \mathrm{DP} \geq 24)$. The tuber starch of water chestnut displayed an A-type X-ray diffraction pattern showing a strong diffraction peak at $2 \Theta$ values of $15.18^{\circ}, 17.13^{\circ}$, and $23.1^{\circ}$, and a weak peak at $2 \Theta$ values of $18.1^{\circ}, 20.06^{\circ}$, and $26.69^{\circ}$. Their crystallinity was $28.6 \%$ and the mean starch granule size was $21.5 \mu \mathrm{m}$.

Key words: amylose; Eleocharis kuroguwai; starch; waterchestnut.

\section{INTRODUCTION}

Water chestnut (Eleocharis kuroguwai Ohwi) was reported to be one of the most important perennial weed species in temperate regions including Korea (Kim 1983) and Japan (Takabayashi 1988). Water chestnut is not easy to be controlled by the use of herbicides. It is also one of the most important weed species in machine-transplanted rice fields (Chae and Guh 1999) and direct water-sown rice fields (Kim and
Pyon 1998) in Korea. Water chestnut is an erect, tuberforming perennial.

Plant height, number of tillers and top fresh weight per $\mathrm{m}^{2}$ are $50 \sim 90 \mathrm{~cm}, 500 \sim 875$ and $175 \sim 750 \mathrm{~g}$, respectively. This weed forms tubers deep in the soil. These propagules die when the soil temperature falls below -5 to $-7^{\circ} \mathrm{C}$ and cannot survive under dry conditions (Auld et al. 1996). Vegetative propagules with a water content of about $70 \%$ die when their water content decreases to $30 \%$ (Auld et al. 1996). It is

\footnotetext{
${ }^{1}$ Division of Crop Science, Gyeongsangbuk-do Agricultural Research \& Extension Services, Daegu 702-708, Korea.

${ }^{2}$ Division of Environmental Science \& Engineering, Keimyung University, Daegu 704-701, Korea.

${ }^{3}$ Department of Clinical Pathology, Jeju Halla University, Jeju Special Self-Governing Province, Jeju 690-708, Korea.

* 연락저자(Corresponding author) : Phone)+82-64-741-7403, Fax)+82-64-747-3989, E-mail) shiny@ @chu.ac.kr
} 
mainly found in temperate countries, such as China, Korea and Japan in irrigated rice areas.

Apart from these ecological and physiological characteristics, tuber starch of this weed has been sometimes used as food. Less is known about the physicochemical properties of main component, starch in water chestnut. Since the water chestnut is potential new starch resource, its physicochemical properties were investigated in this study.

\section{MATERIALS AND METHODS}

The alkaline steeping procedure to isolate tuber starch of water chestnut was followed by the method of Wang et al. (2001). The two or three years grown tubers of water chestnut were collected at experimental fields of Gyeongsangbuk-do Provincial Agricultural Research \& Extension Services, Daegu, Republic of Korea.

Water chestnut flour $(20 \mathrm{~g})$ was steeped in $40 \mathrm{~mL}$ of $0.1 \% \mathrm{NaOH}$ for $18 \mathrm{hr}$. The slurry was blended with a Waring blender at a high speed for $2 \mathrm{~min}$, passed through 100 mesh sifter and centrifuged at $1,300 \times g$ for $10 \mathrm{~min}$. The top layer was carefully removed and bottom layer was reslurried and washed three times with $0.1 \% \mathrm{NaOH}$. The top layer was removed and then the starch layer was washed with deionized water and centrifuged. The combined starch was then reslurried and neutralized with $0.1 \mathrm{~N} \mathrm{HCl}$ to $\mathrm{pH} 6.5$, and washed with deionized water four times, centrifuged, dried in an oven at $45^{\circ} \mathrm{C}$ for $48 \mathrm{hr}$.

The absorption curves of starch and iodine complexes were measured by a UV/VIS spectrophotometer (Model Evolution 300, Thermo Electron Corporation, USA) at 700 to $500 \mathrm{~nm}$. A solution containing $2 \mathrm{mg}$ iodine and $20 \mathrm{mg}$ potassium iodate was added to $1 \mathrm{mg} \mathrm{NaOH}-$ gelatinized and $\mathrm{HCl}$-neutralized starch, and made up to $25 \mathrm{~mL}$. The wavelength at maximum absorption $\left(\lambda_{\max }\right)$ and blue value (BV), absorbance at $680 \mathrm{~nm}$, were determined. According to the method of Kainuma (1977), amperometric iodinetitration of defatted starch was carried out at $1 \mathrm{~A}$ and $50 \mathrm{mV}$.

The pasting properties of the rice flours $(3 \mathrm{~g}, 14 \%$ moisture basis) in water $(25 \mathrm{~mL})$ were determined using the Rapid Visco Analyzer (RVA, Newport Scientific Pty. Ltd., Narrabeen, Australia). DSC was performed on a Differential Scanning Calorimeter (DSC-SP, Rheometric Scientific, New Castle, DE, USA) and the instrument was calibrated with indium. Starch samples and distilled water $(1: 3$, w/w) were hermetically sealed in aluminum pans, held overnight, and heated from 30 to $120^{\circ} \mathrm{C}$ with $10^{\circ} \mathrm{C} / \mathrm{min}$ heating speed. An empty aluminum pan was used as reference.

Rice starches were then suspended in $5 \mathrm{~mL}$ of methanol, boiled for $10 \mathrm{~min}$, and the homogenate was centrifuged at 2,500 $\mathrm{g}$ for $10 \mathrm{~min}$. The precipitated polyglucan fraction was washed twice with $1 \mathrm{~mL}$ of $90 \%(\mathrm{v} / \mathrm{v})$ methanol, suspended in $5 \mathrm{~mL}$ of distilled water, and then boiled for $60 \mathrm{~min}$. The gelatinized polyglucan sample was added to $50 \mu \mathrm{l}$ of $600 \mathrm{~mm}$ sodium acetate buffer ( $\mathrm{pH} 4.4)$ and $10 \mu 1$ of $2 \%(\mathrm{w} / \mathrm{v})$ $\mathrm{NaN}_{3}$, and hydrolyzed by adding $10 \mu \mathrm{l}$ of Pseudomonas amyloderamosa isoamylase (1,400 units, Seikagaku, Tokyo) at $37^{\circ} \mathrm{C}$ for $24 \mathrm{~h}$. The hydroxyl groups of the debranched glucans were reduced with $25 \mathrm{mg}$ of sodium borohydride under alkaline $\mathrm{pH}$ conditions for $20 \mathrm{~h}$ by the method of Nagamine and Komae (1996).

The precipitate was dried in vacuum at room temperature. The reduced isoamylolysate sample was dissolved in $30 \mu \mathrm{l}$ of $1 \mathrm{~m} \mathrm{NaOH}$ for $60 \mathrm{~min}$ and diluted with $270 \mu$ l of distilled water. A $50 \mu \mathrm{L}$ aliquot of the preparation was injected into a BioLC (model DX-500, Dionex, Sunnyvale, CA) equipped with a pulsed amperometric detector and a CarboPac PA-1 column (4 mm $\times 25 \mathrm{~cm}$ ). Size fractionation of a-1,4-glucans was performed with a linear gradient of sodium acetate (50 $500 \mathrm{~mm}$ ) in $0.1 \mathrm{~m} \mathrm{NaOH}$ at a flow rate of $1 \mathrm{~mL} \mathrm{~min}^{-1}$. Purified starch granules were sputter coated with gold and examined with scanning electron microscope (Model JSM-56000LV, JEOL) at 10 or $20 \mathrm{kV}$. DSC of starches was measured as described by Fujita et al. (2003). 
X-ray diffraction pattern of starches was obtained with copper, nickel foil-filtered, Ka-radiation using a diffractometer RINT 2000 at $50 \mathrm{kV}$ and $27 \mathrm{~mA}$. The collected data for tuber yield were analyzed by using SAS package for Duncan's multiple range tests.

\section{RESULTS AND DISCUSSION}

Wavelength at maximum absorption, absorbance at $680 \mathrm{~nm}$, starch and amylose contents for the tuber of water chestnut are presented in Table 1. Blue value was 0.267 at $680 \mathrm{~nm}$. The starch and amylose contents in tuber flours of water chestnut were $85.6 \%$ and $19.3 \%$, respectively.

Table 2 presents pasting properties of tuber flour in water chestnut determined by Rapid Visco Analyser (RVU). Pasting time and temperature in tuber flours of water chestnut were $2.67 \mathrm{~min}$. and $69.8^{\circ} \mathrm{C}$, respectively. Peak viscosity (PKV), hot paste viscosity (HPV) and cooling peak viscosity (CPV) were 5,679, 3,146 and 4,262 RVU, respectively. Among these parameters, hot paste viscosity is influenced by the rate of amylose

Table 1. Wavelength at maximum absorption $\left(\lambda_{\max }\right)$, absorbance at $680 \mathrm{~nm}$ (blue value), starch and amylose content in water chestnut.

\begin{tabular}{cccc}
\hline $\begin{array}{c}\lambda \max \\
(\mathrm{nm})\end{array}$ & $\begin{array}{c}\text { Blue value } \\
(\text { at } 680 \mathrm{~nm})\end{array}$ & $\begin{array}{c}\text { Starch } \\
\text { content } \\
(\%)\end{array}$ & $\begin{array}{c}\text { Amylose } \\
\text { content } \\
(\%)\end{array}$ \\
\hline 595 & 0.267 & $85.6 \pm 0.1$ & $19.3 \pm 0.2$ \\
\hline
\end{tabular}

$\overline{\text { Values are means } \pm \text { standard deviations. Starch and amylose }}$ content were calculated by dry weight basis. exudation, amylose-lipid complex formation, granule swelling, and completion between exudated amylose and remaining granules for free water, while the cold paste viscosity is largely determined by the retrogradation tendency of the soluble amylose upon cooling (Olkku and Rha 1978).

Pasting properties are dependent on the rigidity of starch granules, which in turn affect the granule swelling potential (Sandhya et al. 1989) and the amount of amylose leaching out in the solution (Morris 1990). Parades-Lopez (1994) reported that low peak viscosity is due to short chain length and to irreversible damage treated with alkaline media. Setback values in nonglutinous proso millet starches were higher than the waxy proso millet starches. It is generally recognized that if viscosity of setback is high, the retrogradation of starch paste would progress rapidly (Leeiarathi $e t$ al. 1987).

The transition temperatures $(\mathrm{T} o, \mathrm{~T} p$, and $\mathrm{T} c$ ), range $(R, \mathrm{~T} c-\mathrm{T} o)$, enthalpies of gelatinization $(\Delta H \mathrm{gel})$, and peak height indices (PHI) of tuber starch from water chestnut were determined by differential scanning calorimeter (Table 3). In three transition parameters, onset temperature $\left(\mathrm{T}_{o}\right)$, peak temperature $\left(\mathrm{T}_{p}\right)$, and conclusion temperature $\left(\mathrm{T}_{c}\right)$ were $64.1,68.5$ and 72.3 , respectively. Gelatinization enthalpy ( $\Delta H$ gel) was 4.48 $\mathrm{J} / \mathrm{g}$. Gelatinization temperature may be attributed to the differences in amylose content, size, shape, and distribution of starch granules, and to the internal arrangement of starch fractions within the granules (Grelda et al. 1997).

Transition temperatures are influenced by the molecular architecture of the crystalline region, which cor-

Table 2. Pasting properties of tuber flours of water chestnut.

\begin{tabular}{|c|c|c|c|c|c|c|}
\hline \multirow{2}{*}{$\begin{array}{l}\text { Pasting } \\
\text { time } \\
\text { (min.) }\end{array}$} & \multirow{2}{*}{$\begin{array}{c}\text { Pasting } \\
\text { temp. } \\
\left({ }^{\circ} \mathrm{C}\right)\end{array}$} & \multicolumn{5}{|c|}{ Viscosity (RVU) } \\
\hline & & PKV & HPV & $\mathrm{CPV}$ & Breakdown & Setback \\
\hline 2.67 & 69.8 & 5,679 & 3,146 & 4,262 & 2,533 & $-1,417$ \\
\hline
\end{tabular}

${ }^{\dagger}$ PKV, Peak viscosity; HPV, Hot paste viscosity; CPV, Cooling peak viscosity. 
Table 3. Thermal properties of tuber starch determined by differential scanning calorimeter (DSC) in water chestnut.

\begin{tabular}{cccccc}
\hline \multicolumn{7}{c}{ Gelatinization parameters } \\
\hline To $\left({ }^{\circ} \mathrm{C}\right)$ & $\mathrm{T} p\left({ }^{\circ} \mathrm{C}\right)$ & $\mathrm{T} c\left({ }^{\circ} \mathrm{C}\right)$ & $\Delta H_{\text {gel }}(\mathrm{J} / \mathrm{g})$ & $\mathrm{PHI}$ & $R$ \\
\hline $64.1 \pm 0.2$ & $68.5 \pm 0.1$ & $72.3 \pm 0.2$ & 4.48 & 1.02 & 8.2 \\
\hline
\end{tabular}

All values shown are means \pm standard deviations. To, onset temperature; $\mathrm{T} p$, peak temperature; $\mathrm{T} c$, conclusion temperature; $\mathrm{R}$, gelatinization range ( $\mathrm{T} c-\mathrm{T} o$ ); $\Delta \mathrm{H}$, enthalpy of gelatinization (based on starch dry weight); PHI, peak height index $\Delta \mathrm{H}$ gel/ $(\mathrm{T} p-\mathrm{T} o)$

respond to the amylose and amylopectin ration (Noda et al. 1998). The $\Delta H$ gel of starch suggested that the double helices (formed by the outer branches of adjacent amylopectin chains) that unravel and melt during gelatinization are strongly associated within the native granule. The gelatinization enthalpy reflects the overall measure of crystallinity (quality and quantity of crystallites) of amylopectin and is an indicator of the loss of molecular order within the granules (Tester and Morrison 1990). PHI is the ratio of $\Delta H$ gel for gelatinization to the gelatinization temperatures range and is a measure of uniformity in gelatinization. Tuber starch in PHI was 1.02, indicating that the high PHI value of starch may be attributed to the presence of large-size granules (Aggarwal et al. 2004).

Chain length distribution represents the structural feature of polyglucans such as amylopectin and glycogen. Analysis by HPAEC-PAD was performed to examine the fine structures of polyglucans in tuber starch of water chestnut (Fig. 1).

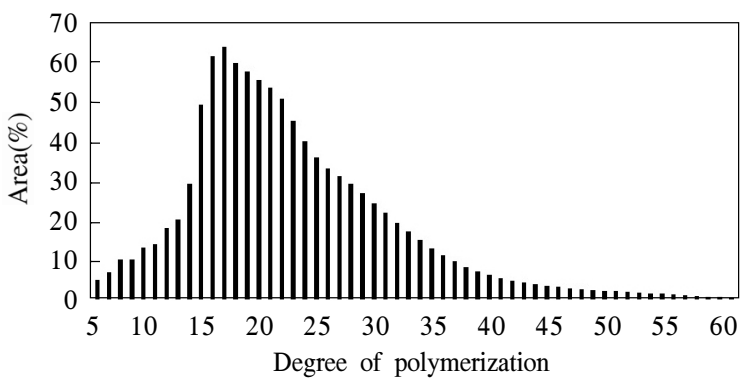

Fig. 1. Distribution of amylopectin branch chain-length of water chestnut determined by using a high-performance anion-exchange chromatography coupled with a pulsed amperometric detector (HPAEC-PAD).
In general, A-type starch has peaks at shorter chainlengths (first peak at dp 12 14, second peak at dp 1 $2 \sim 14$, second peak at dp $41 \sim 51$ ) than B-type starch (first peak at dp 14 16, second peak at $48 \sim 53$ ). A-type starch has a smaller proportion $(11.4 \%)$ of short chains $(\mathrm{dp} \geq 12)$ and larger proportions $(57.2 \%)$ of short chains $(13 \leq \mathrm{DP} \geq 24)$. All cereal starches display very short chains of dp 6 and a gradual increase in chains dp 7 9. Some tuber, root and mung bean starch also displays a higher proportion of dp 6 than dp 6 and 8 (Jane et al. 1999).

X-ray diffraction study was performed to obtain qualitative evidence for crystalline starch. X-ray diffraction angles, crystallinity and scanning electron photographs of water chestnut starches are presented in Table 4, Table 5, Figure 2, and Figure 3, respectively. The profile for water chestnut starch has distinctive feature of A-type starch such as cereal crops, corn and rice starches. Furthermore, its feature of water chestnut was the same with that of Eleocharis dulcis starch $(\mathrm{Yu}$ et al. 1999).

The tuber starch of water chestnut displayed an A-type X-ray diffraction pattern showing the strong diffraction peak at $2 \Theta$ values of $15.18^{\circ}, 17.13^{\circ}$, and $23.1^{\circ}$, and a small peak at $2 \Theta$ values of $18.1^{\circ}, 20.06^{\circ}$,

Table 4. X-ray diffraction data of tuber starch from water chestnut.

\begin{tabular}{ll}
\hline \multicolumn{2}{l}{ Diffraction peaks at $2 \theta$ values } \\
\hline Strong peak & Weak peak \\
\hline $15.18^{\circ}, 17.13^{\circ}, 23.1^{\circ}$ & $18.1^{\circ}, 20.06^{\circ}, 26.69^{\circ}$ \\
\hline
\end{tabular}

(C) 2012 Korean Society of Weed Science 
Table 5. Crystalpatternanddegreeofcrystallinityof tuber starch from water chestnut.

\begin{tabular}{ccccccc}
\hline \multirow{2}{*}{$\begin{array}{c}\text { Starch granule } \\
\text { size }(\mu \mathrm{m})\end{array}$} & $\begin{array}{c}\text { Degree of } \\
\text { Crystallinity } \\
(\%)\end{array}$ & Crystal pattern & & \multicolumn{4}{c}{$\%$ Distribution } \\
\cline { 4 - 7 } & $21.5 \pm 0.3$ & A & 11.4 & 57.2 & 24.1 & 8.7 \\
\hline
\end{tabular}

Degree of crystallinity was determined following equation as $\mathrm{Xc}=\mathrm{Ac} /(\mathrm{Ac}+\mathrm{Aa})$; Ac : the crystallized area; Aa : the amorphous area on the X-ray diffractogram.

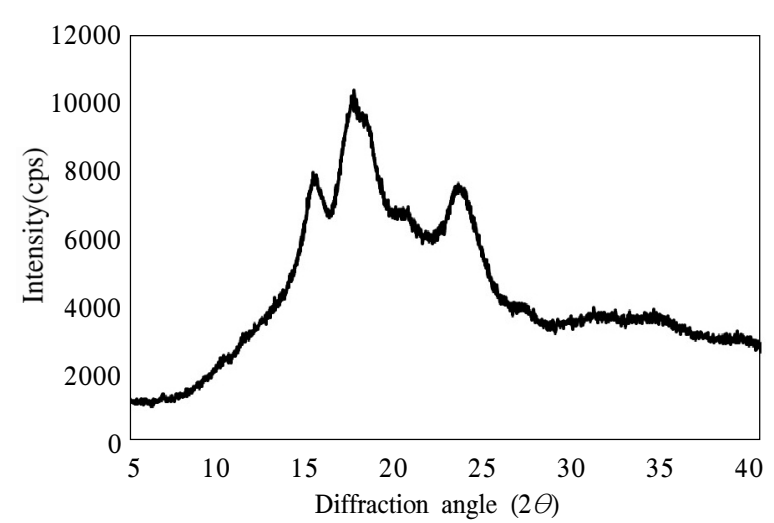

Fig. 2. X-ray diffraction diagram of tuber starch in water chestnut.

and $26.69^{\circ}$ (Table 4, Table 5, and Fig. 2). Their crystallinity was $28.6 \%$. The degree of crystalline in starch is strongly dependent on amylose content (Cheetham et al. 1998). It is generally reported that A-type and B-type starches reflect the presence of parallel stranded double helices. Parallel stranded double helices, which are packed quite closely in A-type structures but are more loosely associated for B-type starches (Ratnayake et al. 2001).
Scanning electron microscopy revealed that the mean starch granule size was $21.5 \mu \mathrm{m}$ in diameter (Fig. 3). Starch granules of water chestnut showed mostly polygonal-round, oval, spherical in shape. In brief, the variation in size and shape off starch granules may be due to the biological origin (Svegmark and Hermansson 1993). The morphology of starch granules depends on the biochemistry of the chloroplast or amyloplast, as well as physiology of the plant (Badenhuizen 1969). In conclusion, it is supposed that new natural starches are essential for their best use and also to increase the utilization of starchy flours including utilization as an additive in food industry.

\section{요 약}

본 연구는 다년생 잡초인 올방개 괴경의 전분에 관 한 이화학적 특성을 알아보기 위하여 수행되었다. 올 방개 괴경 분말의 호화 점도 특성은 최고점도 5,679 , 강하점도 426 이었고, 괴경 전분의 호화 개시온도는 $64.1^{\circ} \mathrm{C}$ 로 낮았으며 최종온도는 $72.3^{\circ} \mathrm{C}$ 이었다. 전분입

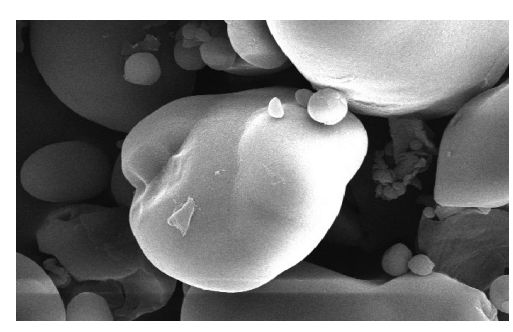

(A)

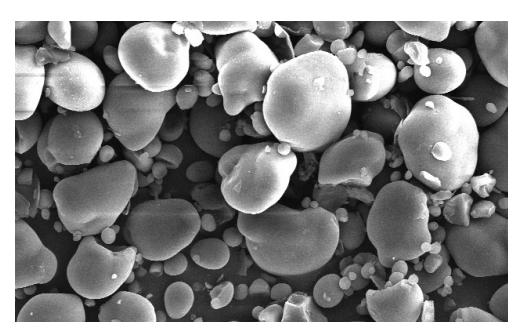

(B)

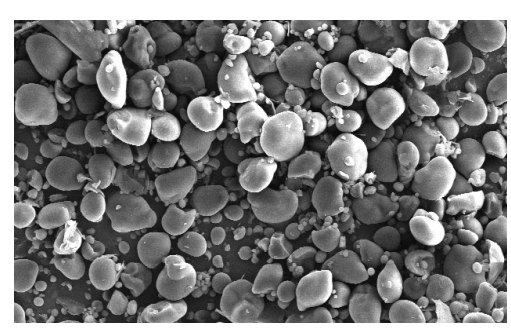

(C)

Fig. 3. Scanning electron micrograph of tuber starch in water chestnut. From the left, magnification $(A) \times 3000,(B) \times 1000$, and (C) $\times 500$. 
자의 X-ray 회절각은 $15.18^{\circ}, 17.13^{\circ}, 23.1^{\circ}$ 에서 강한 피크를 보였으며, $18.1^{\circ}, 20.06^{\circ}, 26.69^{\circ}$ 에서 약한 피크 를 보였다. 올방개 괴경 전분의 결정화율은 $28.6 \%$ 이고 괴경 전분 입자의 모양은 둥글면서 부분적으로 눌린 형태였으며 평균 입자 크기는 $21.5 \mu \mathrm{m}$ 이었다.

\section{REFERENCES}

Aggarwal, V., N. Singh, S. S. Kamboj and P. S. Brar, 2004. Some properties of seeds and starches separated from different Indian pea cultivars. Food Chem. 85:585-590.

Auld, B. A., and K. U. Kim. 1996. Weed management in rice. FAO plant production and protection paper. FAO of the United Nations. 17-18.

Badenhuizen, N. P. 1969. The biogenesis of starch granules in higher plants. New York, Appleton Crofts.

Chae, J. C., and J. O. Guh. 1999. Occurrence and control of weeds in direct-seeded rice paddy in Korean J. Weed Sci. Tech. 44(4):391-404.

Cheetham, N. W. H, and L. Norman. 1998. Variation in crystalline type with amylose content in maize starch granules: an X-ray powder diffraction study. Carbohydrate Polymers. 36(4):277-284.

Fujita, N., A. Kubo, D. S. Suh, K. S. Wong, J. L. Jane, K. Ozawa, F. Takaiwa, Y. Inaba and Y. Nakamura. 2003. Antisense inhibition of isoamylase alters the structure of amylopectin and the physicochemical properties of starch in rice endosperm. Plant Cell Physiol. 44: 607-618.

Grelda, A., G. A. Yañez-Farias, J. G. Moreno-Valencia, M. R. Falcón-Villa and J. M. Barrón-Hoyos. 1997. Isolation and partial characterization of starches from dry beans (Phaseolus vulgaris) and Chickpeas (Cicer arietinum), Grown in Sonora, Mexico. Starch 49(9):341-345.

Jane, J., Y. Y. Chen, L. F. Lee, A. E. McPherson, K. S. Wong, M. Radosavljevic and T. Kasemsuwan. 1999. Effects of amylopectin branch chain length and amylose content on the gelatinization and pating properties of starch. Cereal Chem. 76(5): 629-637.

Kainuma, K. 1977. Handbook of Starch Science. In : Nikuni J. et al. (eds.). Asakara Shoten, Japan. pp. 202.

Kim, H. H., and J. Y. Pyon. 1998. Weed occurrence and yield loss due to weeds in different direct seeded rice paddy fields. Korean J. Weed Sci.18: 12-19.

Kim, K. U. 1983. Control of perennial weeds in rice in temperate zones. In: Weed control in rice. IRRI, Los Banos, Philippines, 243-253.

Leeiarathi, K., D. Indrani and J. S. Sidhu. 1987. Amylograph pasting behavior of cereal and tuber starches. Starch 39:378-381.

Morris, V. J. 1990. Starch gelation and retrogradation. Trends Food Sci. Technol. 1:2-6.

Nagamine, T. and K. Komae. 1996. Improvement of method for chain-length distribution analysis of wheat amylopectin. J. Chromatogr. 732:255-259.

Noda, T., Y. Takahata, T. Sato, I. Suda, T. Morishitta and K. Ishiguro. 1998. Relationships between chain length distribution of amylopectin and gelatinization properties within the same botanical origin for sweet potato and buckwheat. Carbohydrate Polymers 37:153-158.

Olkku, J. and C. Rha. 1978. Gelatinization of starch and wheat flour starch - A review. Food Chem. 3: 293-317.

Parades-Lopez, O. 1994. Amaranth carbohydrate, in amaranth biology, chemistry and technology, O Parades-Lopez, ed, CRC Press, Boca Raton, USA. Ratnayake, W. S., R. Hoover, F. Shahidi, C. Perera and J. Jane. 2001. Composition, molecular structure, and physicochemical properties of starches from four field pea (Pisum sativum L.) cultivars. Food Chem. 74(2):189-202.

Sandhya S., M.R. Rani and K. R. Bhattacharya. 1989. Rheology of rice flour pastes: effect of variety, concentration, and temperature and time of cook-

(C) 2012 Korean Society of Weed Science 
ing. J. Texture Stud. 20:127-137.

Svegmark, K. and K. A. Hermansson. 1993. Microstructure and rheological properties of composites of potato starches granules and amylose. a comparison of observed and predicted structure. Food Struct. 12:181-193.

Takabayashi, M. 1988. Weed management practices for rice farming in Japan. In : Proceedings of the National Seminar and Workshop on Rice Field Weed Management, 25-31.

Tester, R. F. and W. R. Morrison. 1990. Swelling and gelatinization of cereal starches. I. Effect of amylopectin, amylose and lipids. Cereal Chemistry 67:551-557.

Wang, L. and Y. J. Wang. 2001. Comparison of protease digestion at neutral $\mathrm{pH}$ with alkaline steeping method for rice starch isolation. Cereal Chem. 78:690-692.

Yu, B., S. Fujii and K. Kobe. 1999. Physicochemical properties of Huaishan (Rhizoma dioscorea) and Matai (Eleocharis dulis) starches. Starch 5-10. 